\title{
PAMPHLET OF THE ARETHAS OF CAESAREA AGAINST NICHOLAS MYSTICUS AND EMPEROR ALEXANDER
}

\author{
Dmitriy E. Afinogenov \\ Institute of World History, RAS, Moscow, Russian Federation; \\ Lomonosov Moscow State University, Moscow, Russian Federation
}

\begin{abstract}
Using the demise of ex-Patriarch Euthymios (date of death - August 5, 917) as a pretext, Arethas of Caesarea attacks with vicious blame both deceased Emperor Alexander and prospering and ruling Patriarch Nicholas Mysticus. The article proposes to date the Funerary oration on Euthymios (BHG 652) to August 917, since it was apparently pronounced on occasion of his death and funeral, not on the relics transfer, as it was supposed before. The author analyzes the famous comparison of Euthymios with John Chrysostom, Nikephoros I of Constantinople, and with Photios. Actually, it was Emperor Leo VI who removed Photios and sent him to exile (or relegated to a monastery). This fact classes Euthymios with Arcadius and Eudoxia, and most importantly with image breaker Leo V. This circumstance casts serious doubts on Arethas' motivations. The reason for the positive attitude towards Leo could be, apart from the opposition to Alexander, the fact that at the time of the work's composition Zoe Carbonopsina was the actual regent, who ruled in the name of Leo VI's minor son Constantine VII. The publication contains a Russian translation of the work, the first version in any modern European language ever.

Key words: Byzantine history, Arethas of Caesarea, Euthymios, Patriarch of Constantinople, court intrigues, funerary oration.

Citation. Afinogenov D.E. Pamphlet of the Arethas of Caesarea Against Nicholas Mysticus and Emperor Alexander. Vestnik Volgogradskogo gosudarstvennogo universiteta. Seriya 4, Istoriya. Regionovedenie. Mezhdunarodnye otnosheniya [Science Journal of Volgograd State University. History. Area Studies. International Relations], 2017, vol. 22, no. 5, pp. 6-15 (in Russian). DOI: https://doi.org/10.15688/jvolsu4.2017.5.1
\end{abstract}

УДК 94“917”

ББК 63.3(0)4-92

Дата поступления статьи: 08.08.2017

Дата принятия статьи: 25.09.2017

\section{ПАМФЛЕТ АРЕФЫ КЕСАРИЙСКОГО ПРОТИВ НИКОЛАЯ МИСТИКА И ИМПЕРАТОРА АЛЕКСАНДРА}

Дмитрий Евгеньевич Афиногенов

Институт всеобщей истории РАН, г. Москва, Российская Федерация; Московский государственный университет им. М.В. Ломоносова, г. Москва, Российская Федерация

Аннотация. Используя кончину бывшего патриарха Евфимия (ум. 05.08.917) как предлог, Арефа Кесарийский обрушивается с резкими нападками как на покойного императора Александра (912-913), так и на здравствующего и правящего патриарха Николая Мистика. В статье предлагается датировать «Надгробное слово» (BHG 652) августом 917 г., поскольку оно произнесено по поводу похорон Евфимия в Псамафийском монастыре, а не перенесения его мощей, как предполагалось ранее. Анализируется знаменитое сравнение 
Евфимия с Иоанном Златоустом, Никифором I Константинопольским и Фотием. Это сравнение имплицитно ставит в неудобное положение императора Льва VI, который сместил и сослал Фотия. Тем самым он попадает в один ряд с Аркадием и Евдоксией и, самое главное, с иконоборцем Львом V. По-видимому, похвалы в адрес Льва VI обусловлены главным образом тем, что регентом в это время была Зоя Карвонопсина, правившая от имени малолетнего сына Льва Константина VII.

Публикуется перевод произведения на русский язык, являющийся первым переводом на новоевропейские языки вообще.

Ключевые слова: история Византии, Арефа Кесарийский, Евфимий, патриарх Константинопольский, придворные интриги, надгробная речь.

Цитирование. Афиногенов Д. Е. Памфлет Арефы Кесарийского против Николая Мистика и императора Александра // Вестник Волгоградского государственного университета. Серия 4, История. Регионоведение. Международные отношения. - 2017. - Т. 22, № 5. - С. 6-15. - DOI: https://doi.org/10.15688/jvolsu4.2017.5.1

Автор текста, перевод которого публикуется здесь, широко известен не только византинистам, но и классическим филологам, поскольку именно по его заказу были изготовлены многие рукописи, имеющие первостепенное значение для восстановления текста древнегреческих авторов, в частности знаменитый кодекс A (Bodleianus 56) Платона. Арефа родился в Патрах около 870 г., а умер после 933 года. Последняя дата выводится из того, что он успел поприветствовать на патриаршем престоле юного Феофилакта Лакапина, сына императора Романа. Как писатель Арефа отличался злым языком и весьма темным стилем. Самые известные его произведения - Толкование на Апокалипсис и Похвала Гурию, Самоне и Авиву (BHG 740), а также, возможно, Монемвасийская хроника.

Чтобы понять содержание памфлета, слегка замаскированного под надгробное слово, необходимо вспомнить историю четвертого брака императора Льва VI, полную перипетий и конфликтов. Все началось с того, что отец Льва Василий I Македонянин насильно женил его на Феофано Мартинаки (впоследствии канонизирована). Та родила ему дочь, которая рано умерла. Лев жену ненавидел и хотел отправить ее в монастырь, чему воспрепятствовал его духовник Евфимий. Но в 897 г. она умерла, и император женился на своей давней любовнице Зое Заутцене. Однако и та скончалась через два года, так и не подарив Льву наследника мужского пола. Тогда он женился в третий раз, что, хотя имело прецеденты, было уже нарушением церковных канонов. Но и третья жена, Евдокия Ваияна, умерла в 901 году. Родившийся у нее мальчик прожил всего несколько дней. Отчаявшийся Лев взял в любовницы Зою Карвонопсину, ко- торая и родила ему будущего императора Константина VII Багрянородного в мае 905 года. Теперь перед Львом стояла задача узаконить наследника. В начале 906 г. его венчал с Зоей некий пресвитер Фома. Однако патриарх (с 901 г.) Николай Мистик, несмотря на все просьбы императора, который был готов идти на значительные уступки, в конце концов отказался признавать брак законным, и в 907 г. Лев заменил его на Евфимия, обвинив в соучастии в заговоре Андроника Дуки. Новый патриарх наложил на императора покаяние и добился соборного постановления, согласно которому четвертый брак был, наконец, признан как исключительный случай в порядке «икономии». При этом Фоме, низложенному Николаем, священный сан не вернули, а Зоя так и не была венчана августой.

После смерти Льва 11 мая 912 г. правящим императором стал его брат и номинальный соправитель Александр. Он немедленно созвал собор, низложивший Евфимия как незаконно занявшего кафедру, и восстановил Николая в патриаршем достоинстве. Евфимия избили и сослали в Агафов монастырь ( $\tau \grave{\alpha}$ 'А $\alpha \theta$ ог̃) на Босфоре, ранее подаренный ему Львом VI. После смерти Александра 6 июня 913 г. Николай стал главой регентского совета, однако уже в следующем году был смещен с этой позиции вдовствующей императрицей Зоей. Евфимию предлагали вновь стать патриархом, но он категорически отказался. Умер он 5 или 6 августа 917 г. в том же Агафовом монастыре. В контексте памфлета Арефы важно, что после отказа Евфимия вернуться на кафедру Николай посетил его и между ними состоялось полное примирение.

Между тем, независимо от личных взаимоотношений между Николаем и Евфимием, на- 


\section{ВИЗАНТИЙСКОЕ ПРАВОСЛАВИЕ}

сильственное смещение сначала одного, а потом другого привело к расколу Константинопольской церкви на две партии - николаитов и евфимитов. Понадобился сильный правитель в лице Романа I Лакапина, занявшего престол в 920 г., чтобы положить конец церковной смуте подписанием так называемого «томоса единения» в том же году. В этом конфликте первостепенную роль играли личные амбиции, и прежде всего одного человека - а именно, все того же Арефы, главы евфимитской партии. В его принципиальность верится с трудом, поскольку вначале он выступал резко против четвертого брака (в то время как Николай склонялся к тому, чтобы разрешить его), а затем, после изгнания Николая, посвятил несколько произведений обоснованию прямо противоположной точки зрения. Как можно предположить, Арефа, основываясь на предыдущем опыте, ожидал, что после отстранения Николая от регентства и отказа Евфимия вновь занять его место первым кандидатом на патриарший престол будет он сам. Однако как у бывшего патриарха хватило мудрости примириться с соперником (умение идти на компромисс вообще было отличительной чертой Евфимия), так и у императорской власти оказалось достаточно здравого смысла, чтобы не устраивать чехарду на столичной кафедре и не поляризовать общество дальше. Видимо, разочарование Арефы было очень сильным, свидетельством чему и может служить данный текст.

Издатель «Надгробного слова» Л.Г. Вестеринк полагал, что оно было написано по случаю перенесения мощей Евфимия из ссылки, то есть, надо думать, из Агафова монастыря в Псамафийскую ${ }^{1}$ обитель (игуменом которой Евфимий был до патриаршества) около 920 г. [2, р. 82]. Однако мнение это, по-видимому, ошибочно. При ближайшем рассмотрении текст не дает оснований считать, что тело святого было сначала извлечено из какой-то другой могилы, а потом доставлено в новое место упокоения. После 914 г. Евфимий оставался в Агафовом монастыре добровольно, а вот похоронить себя завещал в часовне Иоанна Предтечи Псамафийского монастыря, рядом с мощами исп. Петра, еп. Гордоринии Фригийской. Поскольку бывший патриарх уже не был ссыльным, у регентов не было никаких оснований препятствовать выполне- нию его завещания, несмотря на возражения действующего патриарха Николая (если они не выдуманы Арефой). Печаль и уныние, упоминаемые в начале произведения, никак не подходят к перенесению мощей, но вполне уместны при похоронах только что умершего человека. Поэтому данный текст можно с уверенностью датировать августом 917 года. Об этом же свидетельствует и упоминание Зои Карвонопсины как одной из жертв злодейств Александра. В 920 г. она была уже снова отстранена от власти и отправлена в монастырь. В таком случае «христолюбивые императоры» - это именно Зоя и малолетний Константин. Тогда становится понятным, почему Арефа не жалеет ругательств в адрес Николая, что вызывало бы вопросы, если бы «томос единения» был уже подписан.

Тем не менее понятно, что создало у Вестеринка впечатление, будто в «Надгробном слове» говорится о перенесении мощей. Дело в том, что Арефа, по всей видимости, сознательно хотел провести параллель между похоронами Евфимия и одним из запоминающихся событий предыдущего века - перенесением мощей патриарха Никифора в марте 847 года. Вот соответствующие отрывки (ср. с гл. 7 по нашей нумерации в тексте Арефы):

(Тело Никифора. - Д. А.) переложенное... в раку, было перенесено на руках священников со светильниками и частым пением псалмов и положено в приготовленный для этого дромон. А когда оно преодолело пролив и приблизилось к набережной Города, богохранимый царь Михаил Новый и самые высокопоставленные сановники, патрикии и прочие, радостно встретили его, держа в руках лампады. И отнеся эту драгоценную раку на собственных плечах с верой и благоговением, они положили ее до времени в Великой Церкви... Когда же они и там вновь сотворили усердные бдения и непрерывное посменное хвалебное пение, [рака] была в сиянии лампадных огней доставлена по главной улице города в храм всехвальных Апостолов.

...И вот, едва избежав людской давки, после того, как священнодействователь исполнил подобающее тайноводительство Богу, тело было положено его руками в святилище, носящем имя Апостолов, в недавно построенной для этого гробнице $[7$, б. 126-127].

Дромон - это военный корабль императорского флота, поэтому у Арефы напраши- 
вается сопоставление с «дворцовым судном» ( так же перемещается из одного храма в другой, едва избегает напора толпы и т. п. Собственно говоря, в заключительном обращении к умершему Арефа прямо сравнивает его с Никифором. Здесь мы видим весьма интересную триаду: Иоанн Златоуст - Никифор Фотий. Параллель между Иоанном и Никифором - не просто лейтмотив цитированного выше сочинения Феофана Пресвитера. Сам патриарх Мефодий на три года отложил перенесение мощей, по всей вероятности, чтобы получить цифру в 33 года: именно столько, по его мнению, прошло между ссылкой Иоанна и перенесением его мощей в Константинополь (405-438). Однако к этим святителям добавляется Фотий. Почему именно он, а не, скажем, тоже причисленный к лику святых патриарх Игнатий, побывавший в ссылке в 858 867 годах? Ответ очевиден: патриархи Иоанн, Никифор, Фотий и Евфимий в ссылке и умерли (поэтому сказано: «гонениями и смертями» ( ют некоторые любопытные выводы: во-первых, становится очевидной фотианская ориентация Арефы ${ }^{2}$ (распря между фотианами и игнатианами продолжалась вплоть до «томоса единения»); во-вторых, оказывается, что имеется в виду не первая ссылка Фотия Василием I в 867-873 г., а вторая, которой его подверг Лев VI сразу после восшествия на престол в 886 году. Но в таком случае столь превозносимый Арефой император Лев попадает в малоприятный контекст: неправедная императрица Евдоксия (новая Иродиада) Иоанн Златоуст; иконоборец Лев V - Никифор; Арефой же обливаемый грязью Александр ${ }^{3}$ - Евфимий; Лев VI - Фотий. Это заставляет задуматься об искренности похвал Льву. Не риторические ли задачи здесь главенствуют? В самом деле, поскольку именно этот император поставил Евфимия, объект восхваления, патриархом да и долгое время был его духовным чадом, Льва нельзя не изображать положительно, тем более что его фигура может представить хороший контраст вечно злоумышлявшему против него брату, обидчику Евфимия Александру. Так или иначе, само возвращение к «Иоанновой» парадигме (неправедный государь против патриарха - защитника канонов и/или веры), столь важной для Византии IX в., весьма примечательно.

Литургическое почитание свт. Евфимия было очень ограниченным. Лишь в некоторых рукописях указывается дата 5 августа, в печатных синаксарях его памяти нет. Напротив, усердно очерняемый Арефой Николай Мистик почитается довольно широко. День его памяти отмечается 16 мая.

«Надгробное слово» (BHG 652) было впервые издано в латинском переводе еще в XVI в. [4, p. 96-106]. Латинский текст был перепечатан, в частности, в PG. T. 106. Col. 787-796. На другие языки, насколько мне известно, это произведение не переводилось. Греческий текст впервые издан А.И. Пападопуло-Керамевсом [5] по московской рукописи ГИМ, Синод. греч. 315 (Владимир 441). Настоящий перевод выполнен по последнему изданию: [2, p. 82-93]. Для удобства мною введена нумерация глав.

\section{Арефы, архиепископа Кесарии Каппадокийской, надгробное слово Евфимию, святейшему патриарху Константинопольскому}

1. Что это, священное собрание, освященный клир, боговдохновенный народ? Что за новое стечение у нас и такое против вероятности торжество, не являющее ничего радостного, ни того, чем обычно торжество красуется, но обнаруживает что ни есть мрачного и угрюмого, плачевного и жалобного, что ни есть тяжкого и плохого, что приключается с людьми в величайших несчастьях, и изобильно сплетает это сему благоговейному собранию, так что оно, похоже, плачет заупокойным рыданием? Так что же это за наказание? Что за постигшая нас страшная язва, которая вообще не дает ни поднять голову, ни прямо смотреть глазами, свободными от слез огорчения?

2. Плач этот доставил вам великий архиерей Божий Евфимий, неподобающим образом поруганный, изгнанный с престола, преступной рукой осужденный на ссылку, подвергнутый смерти в этом мире, преданный видимому погребению. И что из этого - такая причина для плача, а вернее, что из этого не есть 


\section{ВИЗАНТИЙСКОЕ ПРАВОСЛАВИЕ}

основание для совершеннейшей радости и удовольствия и того, чем украшается от века всякий человек, посвятивший себя Богу? Память праведного с похвалами (Прит. 10:7), а похвале свойственно освещаться исповеданием и превознесением, а не смешиваться с плачем и рыданием, что вы сейчас делаете. Так не поступают желающие быть в здравом рассудке, вашей пастве такие дела чужды. Добрый рачитель восстал к Тому, Кто ему желанен, соревнователь удалился к устроителю состязаний, борец отошел к раздающему награды, еще обливаясь потом схватки, еще учащенно и прерывисто дыша от трудов ристалища, получил тамошнее облегчение, стал причастником безмятежной жизни, созерцает красоты того, в чем подвизался, впредь стяжает почетные дары из вседержительной десницы, начал уже наслаждаться тамошним блаженством. Из-за этого нужно было бы ликовать и веселиться, что он вкушает воздаяние на небесах, что от посева своих слез, который он сеял на земле, плача, он теперь с наслаждением собирает урожай и радуется.

3. А для тебя причины совершенного ликования - предлог для рыданий? Это и Богу не угодно, и покойному не подобает. Ведь если в глазах неразумных и кажется, будто он умер, как говорит священноявитель (ср. Прем. 3:27), и исход его посчитали притеснением, а отшествие от нас - сокрушением, но он теперь пребывает в мире, потому что Бог, возвращаясь к следующим словам [Писания], ucnblтал его и нашел его достойным Себя; Он испытал его как золото в горниле и принял его как жертву всесовершенную. Поэтому и во время посещения Его он, когда все $п p a-$ ведники воссияют, как солние (Мф. 13:43), сочетается с чистым и самым беспримесным светом, а тьма и мрак окутают левую часть, и праведник станет против оскорблявших его (Прем. 5:1), если следует верить богоглаголивому пророку, описывающему уготованное отмщение (ср. Мф. 25:34). Но что из этого заслуживает рыданий, что несет царящее [тут] уныние, что доставляет печаль, что не подобает пресвятой душе покойного, какие похвальные черты не сопутствовали его жизни с рождения?

4. Взлелеяла его Селевкия, возводя род к божественному Григорию ${ }^{4}$, которым быв- шее незадолго до нас поколение обогатилось как новым чудотворцем ${ }^{5}$, тоже происходившему из Декаполя Исаврийского, и делом подтверждая и удостоверяя [речение]: род правых благословится (Пс. 111:2). Принял же его вначале Вифинский Олимп, прекраснейшее местопребывание любомудрия в Боге, после же него священная обитель у Астакийского залива, где он тоже сиял свершениями добродетели. Но какие трофеи воздвиг он на нашего общего неприятеля и сколькими победными венцами покрыл свою главу, совершая душевные подвиги, мы предоставляем рассказывать тем самым людям, которые и были рядом с этим непобедимым мужем, и, как очевидцы, доподлинно свидетельствуют о его выносливости в голоде и жажде, крайней скудости в одежде, поскольку он в одном гиматии выдерживал тот невыносимый холод, насильственное стояние на повязках и поручах, которым он отгонял от своих век сон, вместе с божественным Давидом жаждая обрести жилище Богу (ср. Пс. 131:3-5) и место упокоения, где нет волнения житейских обстоятельств, нет бури душ, возмущаемых злыми духами. Итак, предоставляя им и рассказывать это, и гордиться памятью об этом ${ }^{6}$, мы сами прибавим то, что было после.

5. С той поры этот именитый и царственный град имел сего доброго и прославленного героя гостеприимно принимаемым в домах верных и воздающим им плату за гостеприимство такую, которую было справедливо получать привечающим и обихаживающим столь великого мужа. Ведь и женщина из Сарепты ничего не упустила из благодати, присущей Фесвитянину ${ }^{7}$, но получила взамен средства на долгое пропитание, стяжав это гостеприимством по отношению к пророку (см. 3 Цар. 17:8-16). У всех ходила добрая слава о нем, потому что, согласно словам Господа, и не может укрыться город, стоящий на верху горы (Мф. 5:14). Что же затем? Он стал известен императору. Восхищается император достоинствами его добродетели, делает своим другом и сотоварищем ${ }^{8}$ тогдашнего патриарха. Прошло немного времени, и Церковь охватили смута и волнение, которые раздула заносчивость того, кто [ей] тогда правил ${ }^{9}$. Потом виновник такой бури, не справившись с ней, дав Церкви Божией отказную гра- 
моту от своей священной чести, скверный скверно ушел, оставив ее без предстоятельства. Время требовало предстоятеля, вот и нашелся он. Ибо что было предпочтительнее или кто лучше подходил, чем человек, который всем был по душе? Поэтому, что не со многими другими случалось, он возводится на священный престол сего Константинова града решением Церкви всей земли, что под небесами. Видишь, каков он, и сколь велик, и каких покамест заслуживает наград за славу добродетелей?

6. Но как мне излагать последующее, зависть от непотребных, убийство от преступных ${ }^{10}$, свирепый и неправедный суд от судей (о правда Божия и непреложные Его судища), которые ни о чем из священных вещей не заботились, но всецело только об обогащении: ради него они и сами не постеснялись отколоться от [всего] целостного и здравого в Церкви, и, улучив желанный для них момент, эти помраченные земли, стремясь к исполнению домов беззакония (ср. Пс. 73:20), если бы было можно, совершенно не остановились бы ни перед подкапыванием стен, ни перед кражей кошельков, ни если бы предстояло чтото более жестокое. Отсюда непревзойденное их бешенство против архиереев Божиих, потому что не было у них никакого другого оправдания тому, на что они осмелились, кроме распродажи всего священного чина, совершаемой безудержно и откровенно. Отсюда и с этим блаженным, ко всем прочим бесчинствам, которые они совершали, издеваясь над ним - ибо неблагопристойно вновь заводить о них речь и осквернять язык их нечистотой, которыми и варварский глаз, порицая, как должно, погнушался. Потому что присутствовали сарацины с посольством, и приняли участие в этом безобразии, которое было хуже всякого трагического представления, при подобных председательствующих подобные же зрители, ибо по-иному [говорить] нечестиво: это зрелище для верных, а скверным и не посмотреть на представляемые мерзости?

7. Итак, за таким началом последовало и дальнейшее: осуждение к ссылке, оставление всеми знакомыми из-за нависших угроз, когда одни были вынуждены смотреть на желанного им с враждебностью, другие оказались далеко разлучены, то есть отсечены при- ставленной к нему воинской суровостью и стражей, или же по природному для многих небрежению, когда минула надобность, стали бесполезны, поменяв мнение и выказывая к прежде взыскуемому противоположное отношение. Ибо против счастья всегда любит строить козни его противоположность, чтобы ничего у людей не сохранялось без враждебной примеси, но самые блестящие вещи загрязнялись завистью порока.

8. К тому же и видимая гробница, хранящая его, когда христолюбивые императоры победили человеколюбием свирепость и непреклонность тогда еще живого и сотворившего это с ушедшим тирана, и нечестиво осужденный хотя бы после смерти был возвращен близким, чтобы святая земля обетования вновь обрела кости Иосифа, избранными священниками доставляемые и погребаемые. Ибо только приказали императоры, и отовсюду словно по условному знаку (разве не предстояло это так отпраздновать?) стекшиеся толпы сначала провожали страстотерпца из ссылки морским путешествием, неисчислимыми лампадами (некоторые из них доставило царственное боголюбие) освещая водную стихию, и развеивая морское однообразие благоуханными дымами каждений, и достойно величая святителя непрестанными песнопениями. Когда же они пристали к берегу, называемому Равд, дворцовое судно приняло священнейшее тело, и оно было положено в божественном храме мученика Емилиана. Там над Божиим угодником были пропеты надлежащие песнопения, и он был почтен надгробными речами (обряд этот совершал боговдохновенный язык одного из архиереев), а потом священные носилки снова взяли оттуда и принесли в тамошнюю обитель. Поднялся крик от всех, начальников и подчиненных, бедных и богатых, мужчин, женщин и детей, юношей и отроков, и одни называли его отцом по Господу, другие искали в нем пастыря, третьи желали его как заступника, бедняки кормильца, женщины защитника с Богом, дети призывали в наставники, и все - того, кто для всех оказывался утешением в насущной нужде. Так по совершении этого похоронного шествия с восхвалениями пришли и в сей священный храм. Совершив здесь оставшиеся обряды и силой вырвав у хватавших мощи, которые 


\section{ВИЗАНТИЙСКОЕ ПРАВОСЛАВИЕ}

были в опасности стать растерзанными из-за веры сбежавшегося народа, мы положили этого поистине священного человека Божия в здешнюю священную гробницу.

9. Разве мало тебе этого, чтобы описать добродетель этого мужа и Божий Промысел, который взвешивает своих слуг еще при жизни как благоприятными обстоятельствами, так и противоположными им? Не думаю, что кто-то возразит, а только тот, кто полагает, будто беспрепятственно играющая здесь многими удача есть награда за добродетель, а более трудный жизненный путь считает неким наказанием, всегда отмеряемым людям свыше, держась мнения неправильного и вредного для себя самого и чуждого все взвешивающей премудрости.

Но достигнув этого места, нужно теперь исследовать в сравнении происшедшее с этим блаженным и то, что случилось с Александром, и постичь Божию справедливость, уделяющую каждому должное подходящим способом. Один - император и императорского происхождения, испустивший свою жалкую душонку вместе с властью, каких сподобился похорон? Но лучше, немного вернув речь назад, так рассмотреть ту и другую сторону. Стало быть, погребенный здесь, таким образом вскормленный и воспитанный, такими и столькими вещами испытанный в добродетели и украсивший ее, удостоился вот такой кончины и такого погребения, славного и великолепного, как видите, и какое подобает посвященным Богу, и это при том, что нанесшая ему неисцелимый укус змеиная голова еще извивалась с остальным телом и источала многую наглость, чтобы не дать с ним случиться ничему лучшему, пусть и напрасно собиралась дергаться, потому что земная власть заставила его волны рассыпаться в пену. Вот что было с ним.

10. Александр же еще в пеленках увидел всю, какая ни есть, роскошь земного благополучия и воспитан был братом добрым и благоговейным, да и что больше говорить братом. Он, много раз пытаясь устраивать против того заговоры, бывал пойман, однако наказания за злые умыслы против него не понес, как много такого произошло с прежними ${ }^{11}$, но цель его козней только сдерживал и приостанавливал его братоненавистное движение, но сохранял его для царства, хотя не следовало бы, потому что это казалось справедливым тому, против чьей власти замышляли, чтобы без возмущений передать ее соправителю, не претерпевшему никакого зла. После же того, как добросердечнейший и сладостный император Лев, уступая человеческой природе, с миром покинул этот свет, оставив самодержавную участь Александру, тот сразу с первых шагов показал, что никакой пользы не получил от кроткого общения с единокровным, каков он был, и что верна пословица, согласно которой неразумный человек, получив власть, меняется к худшему ${ }^{12}$. Вредный и бесчестный человек, бесстыжий муж, творец всяческого зла, приближенный и причисленный к советникам, - вот кого он хвалил и взял себе в соучастники правления ${ }^{13}$.

11. Поэтому даже если что-то из заговоров против брата было до сих пор скрыто от большинства, это теперь уже явственно открывалось и дерзко обнародовалось. Упразднены были заветы долготерпеливого его спасителя, подвергались оскорблениям и отвергались друзья брата, беззаконно обращались и с самой царственной супругой, ничем не согрешившей, и изгнали ее из дворца, и если бы Господь не оставил земле семя царского рода (ср. Ис. 1:9), то он, устранив ныне счастливо царствующего Константина через оскопление, передал бы Римскую власть славянскому юноше, уродливому видом, а в общении еще уродливее ${ }^{14}$.

12. Делом этих безобразнейших новшеств было и злодеяние в отношении этого блаженного. Ибо воспользовавшись как единомысленными советниками теми, кто, будучи многократно уличен в злоумышлениях против Льва, из-за этого оказались изгнаны с церковных кафедр, а скорее, сами удалились из страха быть пойманными, людьми тяжкими, и зверовидными, и стремившимися лишь к деньгам, он совершил то, что и положено преданному таким негодяям. И остальное я решил опустить, сколько он издевался над святыми, упомянув же только следующее, думаю, покажу всю его извращенность.

13. У христианских императоров, а вернее, у всех христиан есть закон входить в божественные палаты с непокрытой головой, и закон этот был введен и установлен священ- 
ным апостолом Павлом (ср. 1 Кор. 11:4, 7). Отменив этот закон, всемудрые и чистейшие постановили, чтобы в неприкосновенные места входил с покрытой головой человек толстокожий, и свинообразный, и чуть ли не хрюкающий, и в чем только не уподобляющийся беотийской свинье ${ }^{15}$, которому и это было позволено, чтобы он мог поупражняться для больших посягательств. Это и вышло к лучшему. И они ввели его и приставили к священной трапезе, облачив в пурпурную одежду, готовя позор и ему, и себе.

14. Я думаю, это было наказание за злодейство по отношению к этому священному Евфимию. Ибо как только Александр осмелился на это, он лишился рассудка и был уже не в себе, но к упомянутому великому презрению Божества прибавил величайшее и губительное: принеся жертвы статуям на Ипподроме, он получил справедливое воздаяние. Еще не все было совершено из бесчинства, и жалкого человека принесли на носилках в собственные покои, в состоянии ничем не лучше, чем у того Ирода, который, убив Иакова Зеведеева в угоду христоубийцам и напав на первоверховного Петра, получил надлежащее отмщение, посреди торжества и царской свиты закончив жизнь от болезненной опухоли, невероятным образом извергшей червей (cp. Деян. 12:1-23).

15. Так как же и этот наш? Вы знаете злополучнейшие его похороны и торопливое шествие к могиле, при котором сломался царский погребальный одр, словно вознегодовав на нечестивейшую ношу, а несчастное тело издавало сильное и невыносимое зловоние, перебивавшее все благоухание каждений, и удивительным образом распухло. И говорят, что это и внутренние органы еще при жизни изверглось через задний проход, когда плоть стала студенистой, а натянутая кожа уже разлагалась, так что его еле успели позорно и беспорядочно бросить в назначенную выгребную яму ${ }^{16}$.

16. Сравним происшедшее с ним с нашими событиями: и пусть объявится, что́ есть богопослушный и благочестивый, а что наглый и богомерзкий, и как почитается кончина преподобного, а скверного подвергается глумлению. Ибо вдобавок к сказанному он не получил установленных обрядов, ни импера- торского шествия, состоящего из сановников, но из каких-то немногих и почти что простолюдинов, которые для любого исполнили бы обычное, хотя у него было много приверженцев, и ничто не препятствовало собраться, но только то, что по долгу и безотлагательно совершается над самодержцами. Но следовало, чтобы оскорбителю выпали такие похороны как символ тамошних наказаний, которые навлекли содеянные им здесь нечестия.

17. Но с этим так, исполнившим достойные отмщения: а что же внушившие ему это решение, и особенно бьющийся вокруг злой головы хвост? Некоторых мы видели гибель, чья память с шумом погибла (Пс. 9:7), а другому она вот-вот предстоит, ибо стенание убогих не погибнет до конца (Пс. 9:19) и воспоет хор девический, то есть наши святые церкви, победную песнь над новым и самонадеянным фараоном, ушедшим под воду вместе с колесницами и всадниками. Ибо до этого его доведет непреклонность, жестокость и неумолимость.

18. Но оставим это, впредь же вернемся к изначальным речам, завершив предыдущее только вот чем: о, держава архиереев Божиих и радующийся вместе с потерпевшими неправедно ради добродетели, со Авелем жертва зависти, с Иаковом древним - ревности, с Захарией закалаемый, с Иаковом Зеведеевым в угоду иудеям убиваемый, с божественным Афанасием изгоняемый, с Павлом украшаемый петлею ссылки, как тот - исповедания, со златым Иоанном в изгнании умерщвляемый, с превоспетыми Никифором и Фотием гонениями и смертями сопрославляемый: тебя не скрыла могила, но открыла поднебесной земле, не утаила земля, но явила частям своим повсюду, архиерея, достойного поставившего его Бога, достойного проповедника величия Его, достойное и завершение обретшего своих священных трудов. Однако же, имея воздаяния своих трудов и уже пребывая с Вождем и Учителем Христом, да умилостивишь оттуда Его, чтобы остановить бурю, удержать вихрь, успокоить волнение, нам, с тобою перенесшим несправедливость, даровать полезное, или если Он доставит суду победу (Мф. 12:20), или если обидчики, познав, в чем согрешили, принесут достойное раскаяние. 


\section{ПРИМЕЧАНИЯ}

1 Псамафия - район Константинополя близ Золотых ворот и Семибашенного замка. Один из немногих сохранивших византийское название: тур. Samatya.

2 Возможно, Арефа был учеником Фотия, но достоверных подтверждений этому нет. Местами весьма непочтительный тон схолий к «Амфилохиям» Фотия как будто бы даже свидетельствует об обратном. см. в: [3].

3 Критическую оценку всех этих обвинений

${ }^{4}$ Св. Григорий Декаполит, живший в конце VIII - первой половине IX века.

${ }^{5}$ Намек на свт. Григория Чудотворца, епископа Неокесарийского.

${ }^{6}$ Имеются в виду насельники Псамафийского монастыря, один из которых несколько позже написал Житие Евфимия [8] (см. также русский перевод: [1])

7 То есть Илии Пророку.

${ }^{8} \Sigma$ v́́бкүvov, то есть синкеллом (келейником). В Византии эту должность часто занимал кандидат в преемники действующего патриарха.

9 Имеется в виду патриарх Николай I Мистик (901-907;912-925).

${ }^{10}$ В оригинале игра слов: $\tau$ òv $\varphi \theta$ óvov $\tau \tilde{\omega} v$

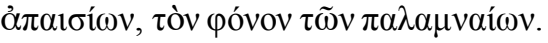

11 Видимо, намек на опалу, которой Василий I подверг Льва, заподозрив его в заговоре. Дело чуть не дошло до ослепления.

${ }^{12}$ CPG I, 212; II, 101.

13 Имеется в виду опять-таки Николай Мистик.

14 Этого юношу звали Василица, см.: [6, p. 379.3-7].

${ }^{15}$ CM. CPG II, 151.

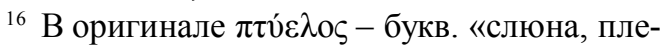
вок», но здесь, по-видимому, использовано как сильное ругательство.

\section{СПИСОК СОКРАЩЕНИЙ}

BHG - Bibliotheca Hagiographica Graeca. In 3 vols. / ed. by F. Halkin. - Bruxelles : Soc. des Bollandistes, 1957. - (Subsidia hagiographica, 8a) ; Novum auctarium Bibliothecae Hagiographicae Graecae. In 3 vol. / ed. F. Halkin. - Bruxelles : Soc. des Bollandistes, 1984. - (Subsidia hagiographica, 65). $C P G$ - Corpus Paroemiographorum Graecorum. In 2 vols. / ed. by E. L. von Leutsch et F. G. Schneidewin. Göttingen : Vandenhoeck et Ruprecht, 1839.

$P G$ - Patrologiae Cursus Completus. Series Graeca. In 161 vols. / ed. by J.-P. Migne. - Paris : Migne, 1857-1887.

\section{СПИСОК ЛИТЕРАТУРЫ}

1. Псамафийская хроника / пер. и коммент. А. П. Каждан // Две византийские хроники Х в. М. : Изд-во восточ. лит., 1959. - С. 7-140.

2. Arethae archiepiscopi Caesariensis scripta minora. In 2 vol. Vol. 1 / rec. L. G. Westerink. - Lipsiae : Teubner, 1968. - xxvii, 362, [1] p.

3. Karlin-Hayter, P. The Emperor Alexander's Bad Name/ P. Karlin-Hayter // Speculum. - 1969. - Vol. 44. P. 585-596.

4. Lipomanus, A. Vitarum sanctorum priscorum patrum. Vol. 3 / A. Lipomanus. - Venetiis : In Viis Sanctae Mariae Formosae, 1554. - 267, [13] p.

5. Papadopulos-Kerameus, A. Monumenta Graeca et Latina ad historiam Photii pertinentia. Vol. I / A. Papadopulos-Kerameus. - Petropoli : Kirschbaum, 1899. $-48 \mathrm{p}$.

6. Theophanes Continuatus. Chronographia // Theophanes Continuatus, Ioannes Cameniata, Symeon Magister, Georgius Monachus / ed. I. Bekkeri. Bonnae : Imp. ed. Weberi, 1838. - P. 1-484.

7. Theophanis Presbyteri Narratio de

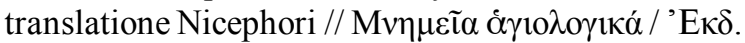

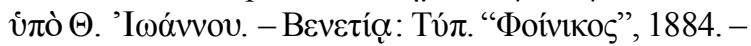
ᄃ. 115-128.

8. Vita Euthymii patriarchae Constantinopolis/ed. by P. Karlin-Hayter. - Bruxelles : Byzantion, 1970. - 267 p.

\section{REFERENCES}

1. Kazhdan A.P., ed. Psamafiyskaya khronika [The Chronicle of Psamathia]. Dve vizantiyskie khroniki Xv. [Two Byzantine Chronicles of the 10th c.]. Moscow, Izd-vo vostochnoy lit-ry Publ., 1959, pp. 7-140.

2. Westerink L.G., ed. Arethae archiepiscopi Caesariensis scripta minora. In 2 vols. Vol. 1. Lipsiae, Teubner, 1968. xxvii, 362, [1] p.

3. Karlin-Hayter P. The Emperor Alexander's Bad Name. Speculum, 1969, vol. 44, pp. 585-596.

4. Lipomanus A. Vitarum sanctorum priscorum patrum. Vol. 3. Venetiis, In Viis Sanctae Mariae Formosae, 1554. 267, [13] p.

5. Papadopulos-Kerameus A. Monumenta Graeca et Latina ad historiam Photii pertinentia. Vol. I. Petropoli, Kirschbaum, 1899. 48 p.

6. Theophanes Continuatus. Chronographia. Bekker I., ed. Theophanes Continuatus, Ioannes Cameniata, Symeon Magister, Georgius Monachus. Bonnae, Imp. Ed. Weberi, 1838, pp. 1-484.

7. Theophanis Presbyteri Narratio de translatione Nicephori. Iōannou Th., ed. Mnēmeia agiologika. Venice, Typ. "Foinikos”, 1884, pp. 115-128.

8. Karlin-Hayter P., ed. Vita Euthymii patriarchae Constantinopolis. Bruxelles, Byzantion, 1970. 267 p. 


\section{Information about the Author}

Dmitriy E. Afinogenov, Doctor of Sciences (Philology), Leading Researcher, Institute of World History, RAS; Professor of Department of Byzantine and Romaic Philology, Lomonosov Moscow State University, Prosp. Leninsky, 32A, 117334 Moscow, Russian Federation, logotheta@mail.ru, https:/orcid.org/ 0000-0002-1192-6728

\section{Информация об авторе}

Дмитрий Евгеньевич Афиногенов, доктор филологических наук, ведущий научный сотрудник, Институт всеобщей истории РАН, профессор кафедры византийской и новогреческой филологии; Московский государственный университет им. М.В. Ломоносова, 117334 г. Москва, Ленинский просп., 32A, logotheta@mail.ru, https://orcid.org/0000-0002-1192-6728 